\title{
Famous Building Stones of Our Nation's Capital
}

The buildings of our Nation's Capital are constructed with rocks from quarries located throughout the United States and many distant lands. The earliest Government buildings, however, were constructed with stones from nearby sources because it was too difficult and expensive to move heavy materials such as stone any great distance without the aid of modern transportation methods, including large cargo ships, trains, and trucks. This Fact Sheet describes the source and appearance of three local stones commonly used in building Washington, D.C.

\section{Aquia Creek Sandstone: White House, Capitol Building, and Gatehouses}

The Aquia Creek sandstone, also called "freestone," was a popular building material between 1790 and 1840. It was prized for construction because of the ease with which it could be carved and transported to building sites along the Potomac River. George Washington selected the Aquia Creek sandstone as the primary material for use in Government buildings. In 1791, and acting on the Government's behalf, Pierre L'Enfant - the architect and engineer selected to design the new city of Washington, D.C.- purchased a quarry about 40 miles south of Washington along Aquia Creek in Stafford County, Virginia. (The peninsula on which the quarry is located subsequently became known as Government Island and today is a natural park preserve and archaeological site.) Stone from this quarry was used for the original portions of the President's House (later known as the White House), some older portions of the U.S. Capitol building, the oldest portions of the U.S. Treasury building, and numerous other smaller structures around the city.

The Aquia Creek sandstone is of Early Cretaceous age (between 100 and 140 million years old). It is composed primarily of sand and pebble-sized quartz and clay pellets and is cemented with silica. Unlike many other sandstones, its matrix is harder than its crystals, which gives it a

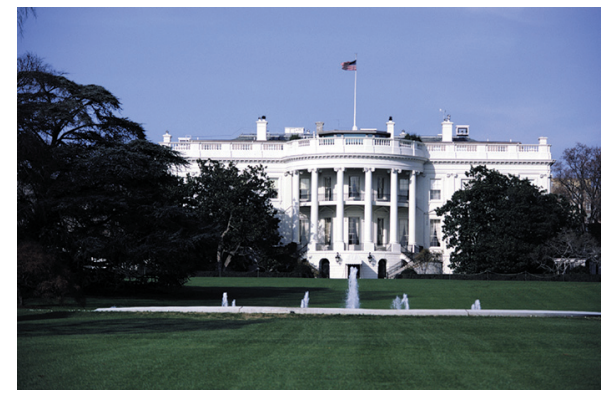

White House quality of toughness without brittle hardness. In appearance, the coarse-grained stone is light gray or tan, and it is streaked or clouded with buff, yellow, or red colors that give it a warm tone.

Unfortunately, the Aquia Creek sandstone proved to have quality-related flaws, and it weathered poorly. After the burning of the White House and Capitol buildings by British troops in 1814, the walls made of Aquia Creek sandstone suffered cracking and pitting. Both buildings were whitewashed and later painted to mask the damage and help protect the stone from weathering. As the defects of the stone became apparent, its use for exteriors declined. One of the last major exterior uses of the stone was at the U.S. Capitol gatehouses and gateposts (circa 1827). One of these gatehouses and three of the gateposts are located at 15th Street and Constitution Avenue NW, and another gatehouse is located farther west at 17 th Street NW.

Interior use of the Aquia Creek sandstone may also be seen in the U.S. Capitol, including in the walls and columns of the rooms adjoining the Rotunda and in the spiral staircase. It was also used in the Little Rotunda tobacco column colonnade in the Senate wing on the same floor, in the famous cornstalk columns in the Senate vestibule, and downstairs in the Doric sandstone columns of the crypt.

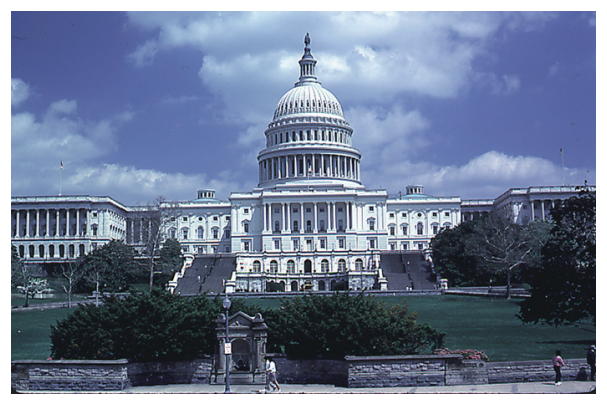

U.S. Capitol

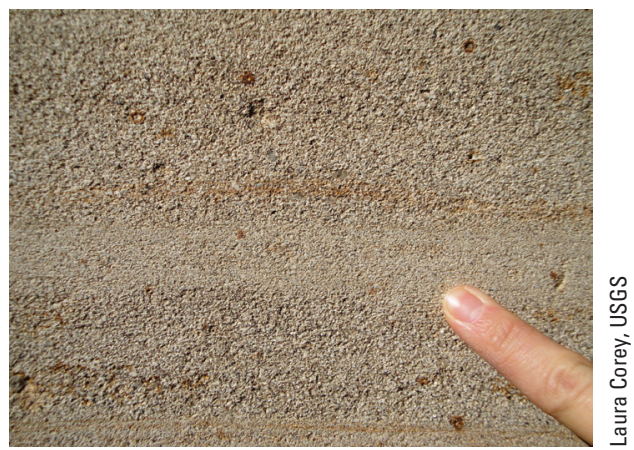

Aquia Creek sandstone

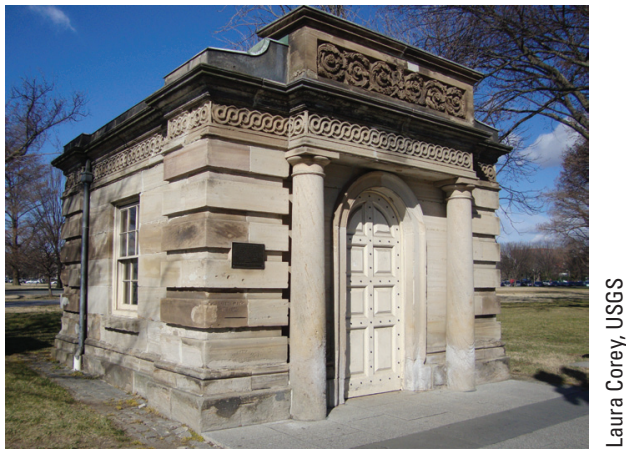

U.S. Capitol gatehouse

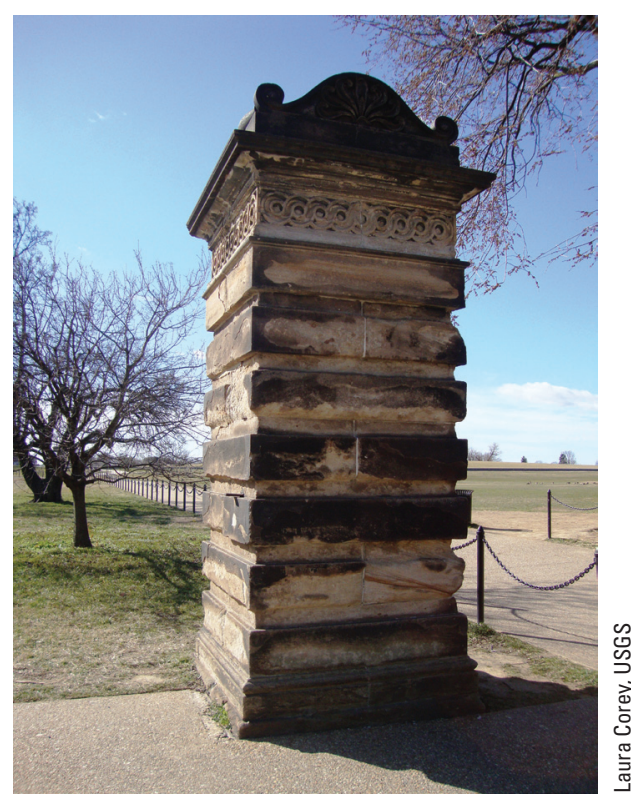

U.S. Capitol gatepost 


\section{Seneca Sandstone: Smithsonian Institution Main Building (the Castle)}

During the "brownstone era," from about 1840 to about 1880, red Seneca sandstone was an extremely popular building stone in Washington. This stone of Triassic age (more than 200 million years old) crops out along the Potomac River in the Triassic lowlands from Seneca, Maryland, to just east of Point of Rocks, Md. Red Seneca sandstone ranges from reddish brown to a deep purplish brown. It is brightly colored when cut but darkens and hardens on exposure to air. Seneca sandstone is generally fine-grained and uniform, and it does not easily scale when exposed to weather.

Several quarries supplied this red sandstone to the city. The best known is located about 20 miles up the Potomac River on the Maryland shore in
Montgomery County just west of Seneca Creek. The remains of the quarry where canal barges were loaded with stone for shipment up or down the canal may still be seen. The ruins of a quarry building that housed saws and machinery for finishing the stone stand nearby. (Note: This site is located on private land.)

The first important Government building to be constructed of this sandstone was the carved and turreted main building of the Smithsonian Institution (the Castle), which was built between 1847 and 1857. The sandstone, when first quarried, was described as lilac gray; after years of oxidation, it is now a dark red. Seneca sandstone is also prominent on the floors and the Rotunda door frames in the U.S. Capitol.

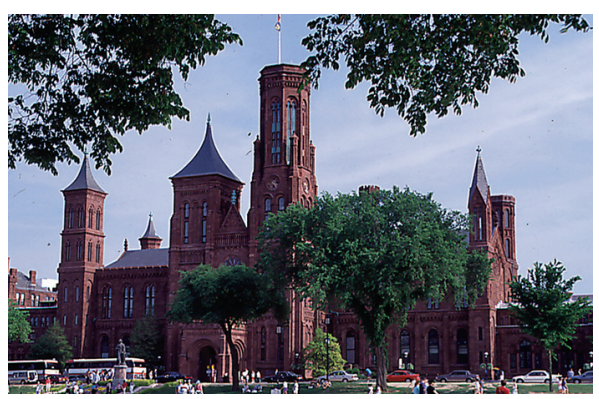

Smithsonian Castle

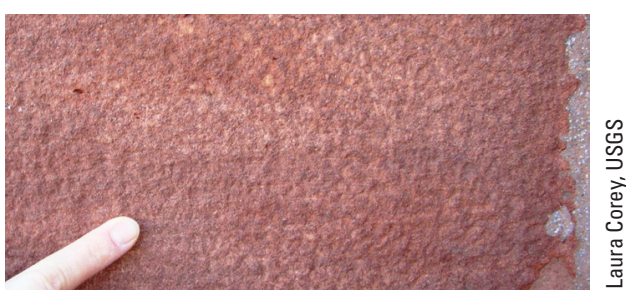

Seneca sandstone

\section{Cockeysville Marble: Washington Monument}

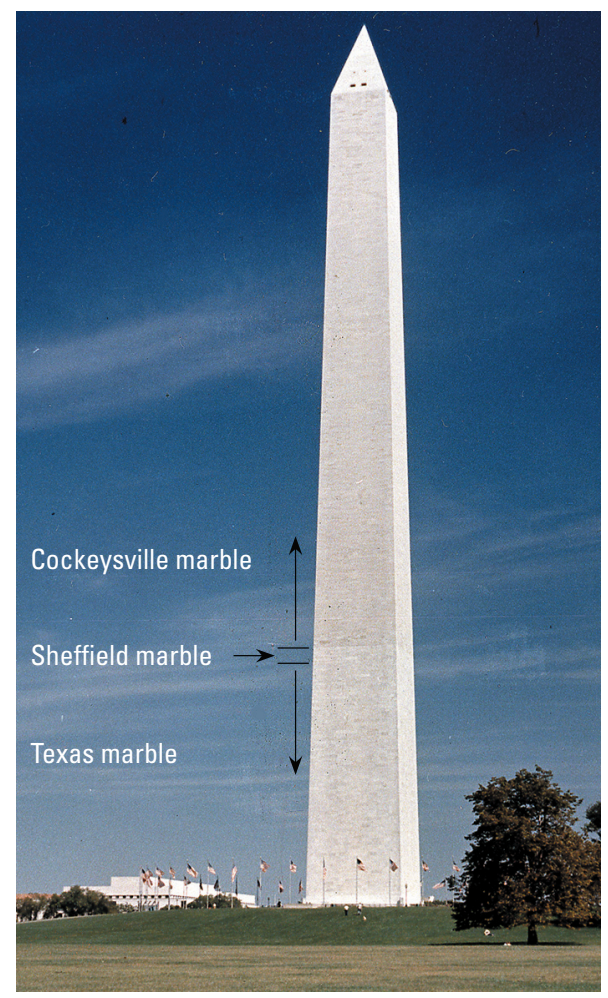

Washington Monument

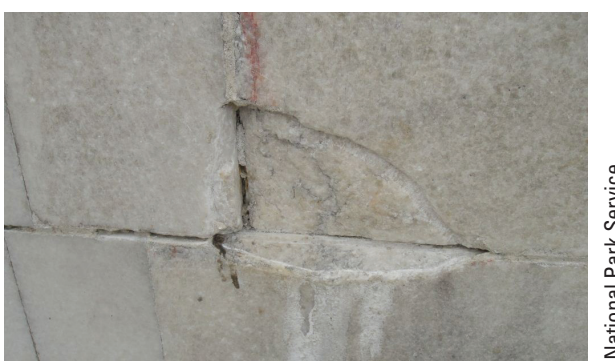

Cockeysville marble from the Washington Monument showing damage caused by the August 2011 earthquake.
Marble eventually replaced sandstone as the most popular building stone in Washington. Of particular note were the three different kinds of regionally metamorphosed marbles of late Precambrian to early Paleozoic age that were used in the construction of the Washington Monument. The first 152 feet of the monument, which was built between 1848 and 1854, is faced with marble from the quarry located at Texas, Md., just north of Baltimore in the Piedmont Province. Work stopped when funds ran out. When construction was about to resume in 1876, the builders discovered that the foundations were inadequate and that the monument was sinking and tilting. To straighten and stabilize the monument, wider subfoundations were constructed to a depth of nearly 37 feet. In 1879, work began again on the upward projection of the monument, and four courses, or rows, of white marble from Sheffield, Massachusetts, were laid above the Texas, Md., marble. Because of difficulties with timely delivery and quality control of the marble, however, the contract with the Sheffield quarry was

\section{For more information, contact:}

\section{U.S. Geological Survey}

Office of Science Quality and Integrity 12201 Sunrise Valley Drive, MS 912

Reston, VA 20192

Web site: http://education.usgs.gov annulled in 1880 . The extensive upper part of the monument was then finished with marble from a quarry located north of Baltimore in Cockeysville, Md. The monument was completed in 1884 , reaching a height of 555 feet and 5 inches.

The three kinds of marble used in the monument can be distinguished by their differences in color. The lower section is the white, coarse-grained, nearly pure calcium carbonate marble from the Texas, Md., quarry. The upper section is built of fine-grained marble from the Cockeysville, Md., quarry. The Cockeysville marble is a clear white stone with a few pale streaks or bands, and its higher magnesium content gives it a pale gray sheen. Both marbles contain veins and pockets of mica and pyrite, which can stain the marble if it is exposed to the elements. In between these two marbles are four rows of a pronounced white marble from the Sheffield, Mass., quarry.

This Fact Sheet is based on a more extensive U.S. Geological Survey publication, "Building Stones of Our Nation's Capital," at http://pubs.usgs.gov/gip/stones. 